\title{
АРХЕТИП РІЗДВЯНОЇ КАЗКИ В УКРАЇНСЬКІЙ ТА ХОРВАТСЬКІЙ ІНТЕРПРЕТАЦІЯХ
}

\author{
Ольга Кравець
}

\author{
Кандидат філологічних наук, доцент, \\ Кафедра слов'янської філології імен проф. І. Свєнціцького, \\ Львівський національний університет імені Івана Франка (УКРАЇНА), \\ 79000, м. Львів, вул. Університетська, 1, \\ e-mail: olhakravets@yahoo.com
}

\begin{abstract}
РЕФЕРАТ
Стаття присвячена вивченню жанру різдвяної казки, «святочному оповіданню» на прикладі порівняльного аналізу окремих творів українських письменників Зої Вишгородської, Івана Керницького та класика хорватської дитячої літератури Нади Івелич. Метою цього дослідження є проаналізувати твори різдвяного циклу трьох самобутніх авторів, двох письменників української діяспори - Зої Вишгородської та Івана Керницького, а також хорватської дитячої письменниці Нади Івелич. Автори мають у своєму доробку однойменні твори із назвою «Різдвяна казка», дуже різні за змістом, але й, водночас, дуже близькі тематично. Дослідницька методика базується на залученні порівняльного, інтертекстуального, описового методів та методу аналізу. Результати. На основі зіставного аналізу творів українських письменників Зої Вишгородської та Івана Керницького, а також хорватської письменниці Нади Івелич вивчається та простежується розвиток жанру різдвяної казки (святочного оповідання) в українській та хорватській літературах минулого століття. Новизна дослідження. Авторка пропонує компаративну літературознавчу студію для вивчення жанру різдвяної казки (святочного оповідання) в українській та хорватській літературах. Практична вартість. Твори українських письменників та хорватської письменниці, класика дитячої літератури, можуть бути цікаві для вивчення в курсах університетських дисциплін - історії літератури, дитячої літератури. Порівняльний аспект вивчення цієї проблеми можна використовувати як ілюстративний матеріал для різних вибіркових курсів.

Ключові слова: порівняльний метод, жанр різдвяної казки, святочне оповідання, Зоя Вишгородська, Іван Керницький, класик хорватської дитячої літератури Нада Івелич, «Різдвяна казка».
\end{abstract}

\section{ARCHETYPE OF THE CHRISTMAS TALE IN UKRAINIAN AND CROATIAN INTERPRETATIONS}

\author{
Olha Kravets' \\ Ph. D. of Philology, Assistant Professor, \\ Department of Slavic Philology, \\ Ivan Franko National University of Lviv (UKRAINE), \\ 79000, Lviv, 1, Universytetska str., \\ e-mail: olhakravets@yahoo.com
}

\begin{abstract}
The article is devoted to studies in the genre of the Christmas fairy tale, the «holiday story» as exemplified by a comparative analysis of individual works by the Ukrainian writers Zoya Vyshhorodska, Ivan Kernytsky and the classic of Croatian children's literature Nada Ivelić. The study is aimed at analyzing the works of the Christmas cycle by the three original authors, viz. two writers of the Ukrainian diaspora - Zoya Vyshhorodska and Ivan Kernytsky - as well as the Croatian children's author Nada Ivelić. The authors have in their oeuvre the same-titled works called «A Christmas Tale», differing much as to the contents, but, simultaneously, very close thematically. The research methodology is based on the involvement of comparative, intertextual, descriptive methods and that of analysis. Results. Based on the comparative analysis of works by the Ukrainian writers Zoya Vyshhorodska and Ivan Kernytsky, as well as the Croatian writer Nada Ivelić, the
\end{abstract}


development of the genre of the Christmas fairy tale (holiday story) in Ukrainian and Croatian literature of the past century is studied and traced. Novelty of the research. The authoress offers a comparative literary research to study the genre of the Christmas fairy tale (holiday story) in Ukrainian and Croatian literature. Practical value. The works of the Ukrainian writers and the Croatian author, the classic of children's literature, can be of interest to studies in university courses, viz. History of Literature, Children's Literature. The comparative aspect of studying this problem can be used as illustrative material for different elective courses.

Key words: comparative method, genre of the Christmas fairy tale, holiday story, Zoya Vyshhorodska, Ivan Kernytsky, classic of Croatian children's literature Nada Ivelić, «Christmas fairy tale».

Жанроформа різдвяної казки, або ж святочного оповідання, відома у багатьох національних літературах як один із найпопулярніших літературних жанрів, адже у ньому творили найвидатніші письменники своєї епохи. «Різдвяна літературна казка постала тоді ж, коли і літературна казка взагалі, тобто у XIX ст.» [8, с. 143] Спочатку Ернст Теодор Гофман «Лускунчиком i мишачим королем» (1816), а згодом і Ганс Крістіан Андерсен «Сніговою королевою» (1846) започатковують традицію різдвяної казки («чудесної оповіді») iз дивовижними фантастичними подіями, захоплюючими персонажами, які одразу перестають бути надбанням однієї національної літератури. Діти в цілому світі знають історію Марі, якій 3 нагоди Різдва подарували Лускунчика; досі зворушують сміливі вчинки та добре серденько відважної Герди, яка вирушила на пошуки Кая.

Згодом, у 1840-х роках опубліковано «Різдвяні казки» Чарльза Діккенса. Саме різдвяні історії цього відомого письменника мали великий успіх. «В літературі вкорінився жанр «різдвяних історій» i писати про це радісне й таємниче свято народження Божого Сина стало ніби «престижно» - багато митців пробувало себе в ньому» [7, с. 216]. Перед читачами постають невеликі за обсягом літературні твори новоствореного жанру різдвяної казки. Про особливості цієї жанроформи пише у своїй розвідці «Святочні оповідання українських письменників» укладачка «Різдвяної трилогії», яку започаткувало видавництво «Свічадо» 2006 року, Зоя Жук. «В більшості з них присутні такі елементи: вагома соціальна складова (детальний опис злиднів, бідності та спровокованих ними людських ганджів та трагедій), образ Дому й Родини, містичний елемент (несподіване втручання чарівних істот у події звичайного життя пересічних «маленьких людей», мотив чуда та покаяння» [7, с. 216].

Серед українських творів, які у 70-х роках XIX століття писали у цій жанроформі, варто згадати дві різдвяні казки класиків української літератури Олени Пчілки «Сосонка» та Марка Черемшини ${ }^{2}$ «Сльоза». В той же час побачили світ і перші спроби перекладів творів Ч. Діккенса, Г.-Х.Андерсена українською мовою - саме вони сприяли розвитку української дитячої літератури. Згодом у світовій дитячій літературі спостерігаємо тенденцію до послаблення зацікавлення жанром різдвяної казки; використання цієї жанроформи дещо навіть маргіналізується; а в українській літературі іiі витісняють інші жанри - оповідання та легенди.

\footnotetext{
1 Олена Пчілка (1849-1930) - відома письменниця, громадська та культурна діячка, етнограф, перекладачка.

2 Марко Черемшина (1874-1927) - український письменник і громадський діяч, адвокат, доктор права.
} 
Різдвяна казка (святочне оповідання) ще донедавна належала до несправедливо заборонених тем в українській літературі загалом, а особливо, в дитячій літературі. Дослідження цієї жанроформи не ставало також предметом українського літературознавчого дискурсу. У дитячому книговиданні радянської доби твори на релігійну тематику підпадають під строгу заборону, вони зазнають ретельної цензури; ця тема надовго вилучається 3 дитячої літератури. Поодиноким осередком, де передовсім автори звертаються до святочної тематики, стають українські автори в діяспорі. «Завдяки їм традиція не лише не обірвалася, але була примножена новими темами...» [7, с. 217]. Саме так виникли гарні й цікаві казки, з'явилась гроно самобутніх авторів, серед яких вирізняються Зоя Вишгородська, Олена Цегельська, Юрій Шкрумеляк та Іван Керницький. Окремо варто сказати про сегмент святочних оповідань та різдвяних казок, присвячені українцям, які опинились в інших країнах Европи, або ж поїхали на далекі поселення. Попри продовження різдвяної тематики із використанням іiї незмінних атрибутів, настроєві ноти налаштовані на мінорне звучання - жаль, туга за своєю далекою домівкою, родиною та батьківщиною висвітлюється у поєднанні з надважливим питанням - збереження власної ідентичности в чужому ментально світі. Ілюстративними прикладами таких творів є «Різдвяна казка» Івана Керницького та «Морозні візерунки» Ольги Мак.

При багатій літературній традиції різдвяної казки як жанру, який постійно втілювався у творах дитячої літератури попередніх періодів, бачимо водночас й сучасних українських дитячих письменників, які звертаються до цієї жанроформи. За роки Незалежности формуються національні особливості української дитячої літератури, закладаються жанрова система й тематичні особливості цього літературного дискурсу.

Цікавою передовсім, на наш погляд, є книжка «Різдвяний павучок» різдвяна казкова історія, яку переповідає малим читачам Іван Малкович, відомий поет та книговидавець. «Цю історію на свят-вечір любив оповідати мій дідусь...» - так розпочинає свою зворушливу оповідь автор $[3$, с. 6]. Ця різдвяна історія відроджує в сучасній українській дитячій літературі забуту традицію написання святочного містерійного оповідання, різдвяної казки, яке упродовж багатьох років творилося лише в українській діяспорі. А ще «Різдвяний повучок» $є$ справжнім прикладом зв'язку поколінь в українській сім'ї та збереженням родинних традицій, адже святвечірню історію розповідає дідусь, іiї слухає внук, а через багато років переповідає своєму синові.

Продовжують традицію родинного читання різдвяні казки письменниць Марії Людкевич («Різдвяний Ангелик»), Зірки Мензатюк («Казка про колядку» та «Снігові колядки»), Лесі Ворониної («Різдвяна казка від слона Гудзика») та iн.

Предметом нашого детальнішого дослідження $є$ твори різдвяного циклу трьох самобутніх авторів - двох письменників української діяспори Івана Керницького та Зої Вишгородської та класика хорватської дитячої літератури письменниці Нади Івелич. Цікавим $є$ той факт, що троє авторів мають 
однойменні твори - це «Різдвяна казка» Зої Вишгородської, «Різдвяна казка» Івана Керницького та «Різдвяна казка» хорватської авторки Нади Івелич.

Зоя Вишгородська - прибране ім'я Олександра Варрави (1926-2013), українського письменника, прозаїка, публіциста та богослова. На еміграції друкувався під цим псевдонімом. Автор низки дитячих творів дидактичного характеру, здебільшого казок [4].

«Тихий і непорушний був ліс у різдвяну ніч. Високо над ним густі хмари обгортали землю, а 3 них не переставав спадати легенький, пухнастий сніг» $[6$, c. 25] - саме так мальовничо розпочинає свою оповідь автор казки. Різдвяний спокій і тишу несподівано переривають чиїсь кроки - ще зовсім молода жінка, провалюючись у снігових заметах, від чогось втікає. Несе щось похапцем закутане в стареньку ковдру. Увесь праліс дуже здивований появою такої несподіваної гості - адже в таку пору ніхто не сподівався на відвідувачів. Стурбований появою людини, ліс стає мимовільним учасником цього сюжету, роль лісу варіюється від тла, на якому відбуваються події, до самостійної функції.

Молода жінка у Святвечір втікає з рідної домівки й села, яке палять вороги, переживає смерть свого любого чоловіка Миколи - «Тікай... Дитину... рятуй...» - i замовк навіки» [6, с. 26], рятує зовсім маленьку дитину (немовля на руках молодої гарної Матері - як персоналій празника Різдва, своєрідна алюзія на народженого Спасителя). Жінка, знеможена, падає із дитиною під пишну Ялинку (автор надає Ялинці антропоморфні якості, вона може промовляти людським голосом та співпереживати, себто проявляти емпатію). У якийсь момент Ялинка «побачила, що під нею лежала молода жінка (може, непритомна, а може, й нежива вже? ...Вона підняла своє засніжене гілля i розпростерла його, наче дах, над матір'ю і немовлятком. «Так, може, хоч сніг не буде на них іти...» - прошепотіла сама до себе» (6, с. 27). Ялинка щиро молиться за матір 3 дитятком - «Боже, допоможи їм, врятуй від смерті!»молилася з тремтінням. Від іiі жалю на ніжних гілочках танув сніг і краплинами сліз спадав на землю» [6, с. 27]. Ялинчину молитву почув Голос. Саме від Нього Ялинка дізнається про Найбільшу Жертву i Чарівний Жар, який «повинен увійти в якесь дерево і в ньому горіти. Тепло і затишно стане тоді навкруги. Але те дерево, яке прийме в себе Чарівний Жар, загине від нього...» [6, с. 28].

Здригнулася від цих слів Ялинка - адже вона ще дуже молода, а щоб порятувати дитинку треба самій загинути! Ялинка звертається за допомогою до різних лісових дерев - може хтось із них прийме в себе Чарівний Жар? Марні були пошуки і переконування Ялинки - ані старий дід Клен, ані могутній лицар Дуб («Щоб я віддавав свою силу і красу для якоїсь людської дитини?») [6, c. 28], ані Ліщина, і навіть Кущ Шишини («Подивилась Ялинка на Кущ Шипшини, а він увесь до землі похилився - так, щоб і не бачити, і не чути, і в вічі не дивитись. Боягуз був, хоч і колючий...») [6, с. 28]. Ніхто 3 дерев не захотів пожертвувати собою задля людського дитятка - лише Ялинка, забувши про себе, врятувала дитинку з матір'ю. «-Я хочу, щоб немовлятко жило! I тієї ж хвилини в іiі тілі загорівся невидимим вогнем Чарівний Жар» $[6$, с. 29]. 
Ялинка палала на цілий ліс, сусіди-дерева здивовано похитували своїм верхів'ям, «дивувалась мати з чуда-порятунку і молилась, дякувала Богові за те, що не дав загинути» [6, с. 30]. Невдовзі сніги повністю замели те незвичайне місце, де сталося чудо. По Ялинці не залишилося ані сліду. «Але кажуть, що в кожний Святий вечір вона з'являється на своїй галявинці і сліпучим світлом осяває темряву лісу. І тоді низько схиляються перед нею, як перед володаркою, всі дерева» $[6$, с. 30]. Ліс став свідком великого різдвяного дива, справжньої Містерії, святом радости й світла.

Події «Різдвяної казки» письменника Івана Керницького переносять читача у далеку Америку. 3 біографічної довідки дізнаємось, що Іван Керницький (1913-1984) - український письменник, вмілий фейлетоніст та дотепний гуморист. Був активним учасником письменницького життя довоєнного літературного Львова, належав до модерністського середовища літературного часопису «Назустріч». Творчу роботу поєднував з редакторською та видавничою практикою. 31949 року жив на еміграції у США, став активний членом Об'єднання українських письменників «Слово». Саме там, у НьюЙорку, поєднуючи творчість та громадську діяльність, став одним із найпопулярніших українських письменників в американській діяспорі. У літературному доробку Івана Керницького маємо багате жанрове та тематичне різноманіття: реалістичні оповідання на селянську тематику, повісті, новели, драми та дитячі твори. Художній світ малої прози письменника надзвичайно барвистий, автор майстерно вибудовує сюжети своїх творів.

«Різдвяна казка» (жанрово іiі можна б було визначити як різдвяна мініатюра) Івана Керницького переносить читача до Нью-Йорка. «Була різдвяна ніч на долині міста Нью-Йорка. Василько спав коло Ялинки, і Ялинка спала. Погасли електричні лампочки і бенгальські вогники. Догоріли свічечки. ... Так, Василько спав і Ялинка спала, та не спали Василькові іграшки, нагромаджені під Ялинкою» [2, с. 33]. Із настанням ночі всі іграшки оживають. У них справжнісінькі збори, адже появилася серед них «невидальщина» - запорізький козак. Дарунок цей - від тітки з Філадельфії - вона його сама одягнула у традиційне козацьке вбрання, навіть шабельку додала! Автор детально описав козацький одяг (смушкова шапка зі шликом, синій жупан) та горду й відважну поставу козака Гриця. Уся іграшкова братія з великим зацікавленням розглядала козачка - навіть відомий на весь світ ковбой Рой Раджерс та вождь могіканів Соколине Око захотіли пізнати його ближче - «-Здоров, приятелю! Скажи нам, звідки ти взявся, такий бравий? Чи ти, бува, не з Індії або з Арабії?..

- Я - козак з України! - відповів малий запорожець.

- О-о! 3 України! - загомоніло братство. - А яке твоє ремесло? Яка професія?

Козачок ударив рукою по шабельці:

- Козаки - це були лицарі, що обороняли свою землю, свою віру і свій нарід від лютих ворогів. А в мирний час - господарили, сіяли хліб, вудили рибу, полювали на звіра...» [2, с. 34].

Іграшкове товариство влаштовує запорожцеві маленьке випробування поцілити стрілою позолочений горішок, з якого він - як справжній нащадок 
козаків - виходить переможцем і справним воїном. Товариство приймає до своєї громади запорожця, відзначивши його «не лише цільне око, а й шляхетне серце» [2, с. 35]. Індіяни, ковбої, матроси та інші славні вояки гукали козачкові «Слава! Слава бравому козакові з України!» і заспівали, як ще один вияв особливої шани, знану на весь світ українську щедрівку:

Щедрик, щедрик, щедрівочка,

Прилетіла ластівочка...

«А малий Василько спав коло Ялинки, усміхаючись крізь сон. Може, це йому і снилася різдвяна казка?..» [2, с. 35].

Іван Керницький творить сюжет своєї різдвяної мініатюри у формі сновидіння - Василько спить, а іграшки збираються на віче. Автор впроваджує у свій текст запорожця Гриця, який розказує чужинцям про Україну та ії славну минувшину. Саме він стає протогероєм «Різдвяної казки», саме він демонструє усі свої найкращі чесноти. Письменник наділяє свого персонажа позитивними рисами - козачок Гриць відважний, завзятий, шляхетний. «Різдвяна казка» пройнята духом патріотизму, любови до своєї рідної землі та гордости за неї.

Ілюстрована книжка «Різдвяна казка» (Božićna bajka) класика хорватської дитячої літератури Нади Івелич (1931-2009) своєю назвою і тематикою творить своєрідний триптих різдвяного циклу із вже згаданими святочними оповіданнями (різдвяними казками) українських авторів Зої Вишгородської та Івана Керницького. Автори мають у своєму доробку однойменні твори із назвою «Різдвяна казка», дуже різні за змістом, але й, водночас, дуже близькі тематично. Деякі мотиви казки Нади Івелич перегукуються 3 «Різдвяною казкою» Зої Вишгородської. В обидвох казках йдеться про зруйновані війною села; українська казка описує події Другої світової війни, а твір хорватської письменниці події оборонної війни в Хорватії 90-х років ХX століття. Хорватська дослідниця Міхайла Савич зазначає, що Нада Івелич не могла оминути у своїй творчості та своїм чуттєвим серцем теми Вітчизняної війни 1991-1995 років. «Domovinski rat nije mogao ostati nezabilježen literarnim perom Nade Ivelić» [5, c. 163].

Варто принагідно зазначити, що «Різдвяна казка» - це не поодинокий твір різдвяного циклу в творчости Нади Івелич. Саме нею 1992 року письменниця розпочинає свій літературний різдвяний цикл. Згодом письменниця публікує низку творів, присвячених цій тематиці: «Knjiga božićnih radosti» (1997), «Uskoro će Božić» (1998), «Veselimo se Božiću» (1998), «Priče za Božić» (2002), «Božićni snovi» (2003). Ось як розпочинає свою оповідь хорватська казкарка: «Lebdeći visoko iznad lijepe zemlje Hrvatske, zvijezda Večernjica ugleda na brijegu malu bijelu crkvu. Crkvica nekoliko puta tako teško uzdahne da se čulo do neba» [1, c. 1]. Головні персонажі казки - Вечірня Зірка та стрийко Місяць спостерігають 3 небесних висот за церковцею та дзвоном, i, бачать, що церковця має величезну діру - «Ali, na njezinu pročelju, sada se dobro vidjelo, zjapila je velika rupa. - Jao! Crkvica je ranjena! - usklikne Večernjica» [1, c. 2].

Минула війна. Наближається час для радощів та прославлення народження Христа, але у зруйнованій церковці панують пустка та тишина, 
довкола жодної живої душі. Небесні світила, яким авторка надає у своїй казці особливої ролі медіаторів між світом людей та тваринним світом, вирішують допомогти бідній церковці - адже незабаром Різдво, цілий світ готується до цього великого християнського свята. Виблискують кольоровими вогниками вітрини магазинів, усюди красуються прикрашені ялинки. «Ljudi se vesele, kupuju darove» [1, c. 3]. Лише церковця сумна та самотня. Нада Івелич у своїй казці створює сильний контраст поміж активними приготуваннями до Різдва та розрушеною гранатою церквою. Цей контраст майстерно візуалізує у своїх ілюстраціях художниця Піка Вончина.

Вечірня Зірка та Місяць скликають на допомогу лісових звірів. На відміну від «Різдвяної казки» Зої Вишгородської, в якій Ялинка, жертвуючи собою, рятує матір з дитятком, на заклик Місяця та Вечірньої Зірки відгукуються усі лісові мешканці: олень, сарна, зайці, їжачки, сови, ведмеді, лисиці та вивірки. Усі разом взялись до роботи і відбудували зруйновану церковцю. Цікавим епізодом в казці хорватської письменниці є розповідь Місяця про Різдво, адже лісові звірі нічого не знали про таке свято. 3 оповіді Вечірньої Зірки вони дізнаються про народження Ісуса у вифлеємській стаєнці, про трьох царів та пастухів, які прийшли віддати шану новонародженому Дитятку. На Святвечір церква сяяла красою та виблискувала святковими вогнями. I старі, і малі повертаються до своїх домівок. Дідо Іван - символічна постать у казці, архетипний символ родини, незнищенности народу та країни. А 3 церковної дзвіниці дзвін сповіщає про початок святкового богослужіння.

Хорватська письменниця використала у «Різдвяній казці» цікавий прийом єднання зооперсонажів 3 людьми - адже всі вони з нагоди Різдва одягають святковий різдвяний одяг. Авторка створила цілу галерею образів із багатим внутрішнім світом, які тепер разом святкують Різдво.

Твори різдвяного циклу українських та хорватських письменників дуже розмаїті. Жанроформа різдвяної казки (святочного оповідання) стає популярним жанром в обидвох національних літературах. Інтерпретацією окремих мотивів можемо стверджувати про витворену жанроформу, яка стала базовою у творчости різних поколінь дитячих письменників в Україні та Хорватії. Однойменна «Різдвяна казка» об'єднує двох українських письменників та класика хорватської дитячої літератури Наду Івелич у своєрідний різдвяний триптих. Усі три різдвяні казки святочного циклу тематизують поняття доброти, яка творить чудеса. Окрім цікавої фабули та антропоморфізації персонажів, казки сповідують християнські вічні істини «onima koji su čista srca, u učima će sjati sve zvijezdice» [1, c. 12] - у чистих серцем в очах сіятимуть усі зорі.

\section{ЛІТЕРАТУРА}

1. Ivelić Nada. Božićna bajka. Zagreb : Tipex, 1992. 14 c.

2. Керницький І. Різдвяна казка. Казки Різдвяного ангела: Твори украӥнських письменників / укладач 3. Жук. Львів : Свічадо, 2008. С. 33-35.

3. Малкович І. Золотий павучок. Київ : А-БА-БА-ГА-ЛА-МА-ГА, 1997. 26 с.

4. Мацько В. Варрава Олександр Олексійович. Енщиклопедія Сучасної Украӥни: електронна версія / НАН України, НТШ. Київ: Інститут енциклопедичних досліджень НАН України, 
2005. URL: http://esu.com.ua/search_articles.php?id=33126 (дата звернення: 08.05.2021).

5. Savić M. Domovinski rat u prozi Nade Iveljić. Zbornik radova s međunarodnoga znanstvenoga skupa Zlatni danci 11 - Život i djelo(vanje) Nade Ivelić. Osijek, 2010. S. 162-172.

6. Вишгородська 3. Різдвяна казка. Казки Різдвяного ангела: Твори українських письменників / укладач 3. Жук. Львів : Свічадо, 2008. С. 25-30.

7. Жук 3. Святочні оповідання українських письменників. Святий вечір: Оповідання украӥнських письменників / упор. З. Жук. Львів : Свічадо, 2007. С. 214-221.

8. Жук 3. Історія Різдва: від ясел до книжкової полиці // Різдвяна ніч: Легенди, казки, оповідання / укладач 3. Живка. Львів: Свічадо, 2008. С. 140-148.

\section{REFERENCES}

1. Ivelić, N. (1992), The Christmas fairy tale [Božićna bajka], Tipex, Zagreb, 14 p. (in Croation).

2. Kernytskyi, I. (2008), The Christmas Tale, Tales of the Christmas Angel: Works of Ukrainian writers, [Rizdviana kazka, Kazky Rizdvianoho anhela: Tvory ukrainskykh pysmennykiv], compiled by Zhuk, Z., Svichado, Lviv, pp. 33-35. (in Ukrainian).

3. Malkovych, I. (1997), The Golden Spider [Zolotyi pavuchok], A-BA-BA-HA-LA-MA-HA, Kyiv, 26 p. (in Ukrainian).

4. Matsko, V. (2005), Varrava Oleksandr Oleksiiovych // Encyclopedia of Modern Ukraine: electronic version / Varrava Oleksandr Oleksiiovych // Entsyklopediia Suchasnoi Ukrainy: elektronna versiia ch. editors: I. Dziuba, A. Zhukovsky and others; NAS of Ukraine, NTSh. Kyiv: Institute of Encyclopedic Research of the National Academy of Sciences of Ukraine, http://esu.com.ua/search articles.php?id=33126 (access date: 08.05.2021) (in Ukrainian).

5. Savić, M. (2010), "Patriotic war in prose of Nada Iveljić" [„,Domovinski rat u prozi Nade Iveljić"], Zbornik radova s međunarodnoga znanstvenoga skupa Zlatni danci 11 - Život $i$ djelo(vanje) Nade Ivelić, Osijek, pp. 162-172. (in Croation).

6. Vyshhorodska, Z. (2008), The Christmas Tale, Tales of the Christmas Angel: Works of Ukrainian writers, [Rizdviana kazka // Kazky Rizdvianoho anhela: Tvory ukrainskykh pysmennykiv], compiled Zhuk, Z., Svichado, Lviv, pp. 25-30. (in Ukrainian).

7. Zhuk Z. (2007), Festive stories of Ukrainian writers, The Holy Evening: Stories of Ukrainian writers, [Sviatochni opovidannia ukrainskykh pysmennykiv, Sviatyi vechir: Opovidannia ukrainskykh pysmennykiv], compiler Zhuk, Z., Svichado, Lviv, pp. 214-221. (in Ukrainian).

8. Zhuk Z. (2008), History of Christmas: from the nursery to the bookshelf, The Christmas Night: Legends, fairy tales, stories, [Istoriia Rizdva: vid yasel do knyzhkovoi polytsi, Rizdviana nich: Lehendy, kazky, opovidannia], compiled by Zhivka, Z., Svichado, Lviv, pp. 140-148. (in Ukrainian).

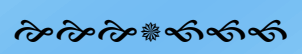

